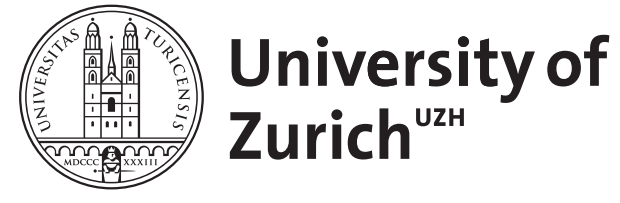

Zurich Open Repository and Archive

University of Zurich

University Library

Strickhofstrasse 39

CH-8057 Zurich

www.zora.uzh.ch

Year: 2018

Islamic leaders and the legal geography of family law in Aceh, Indonesia

Schenk, Christine G

DOI: https://doi.org/10.1111/geoj.12202

Posted at the Zurich Open Repository and Archive, University of Zurich

ZORA URL: https://doi.org/10.5167/uzh-161491

Journal Article

Accepted Version

Originally published at:

Schenk, Christine G (2018). Islamic leaders and the legal geography of family law in Aceh, Indonesia.

Geographical Journal, 184(1):8-18.

DOI: https://doi.org/10.1111/geoj.12202 


\section{Islamic leaders and the legal geography of family law in Aceh, Indonesia}

Christine Schenk, University of Geneva, contact: chgschenk@gmail.com

Forthcoming in: The Geographical Journal, 2018

Part of themed section, guest editors Robinson, DF and Graham, N:

Legal pluralisms, justice and spatial conflicts: New directions in legal geography

\section{Abstract}

This article explores the legal geography of family law in post-colonial Muslim societies. Drawing on a case study in Aceh, Indonesia, it analyses how diverse Islamic leaders were able to influence a controversial administrative reform of family law in the reconstruction period after the 2004 Indian Ocean tsunami. I argue that while Islamic leaders are important stakeholders in law-making in Aceh, they are not a unified collective: rather they mobilise a variety of different practices of legal reasoning to bring legal constructions into agreement. Using the case of an administrative reform of marriage registration, a subordinate regulation in family law, I describe how Islamic leaders deliberate about social issues across their different schools and factions in order to address contemporary problems, while at the same time, mobilising interpretations of Islamic texts as a meaningful tradition for law-making. The analysis builds on ethnographic fieldwork in Aceh, in particular qualitative interviews with civil servants working in the provincial government: Muslim actors, civil rights activists, national experts, international experts, politicians, and diplomats. The article provides impetus to debates in legal geography by illuminating the negotiations of legal 
reasoning in Muslim societies to make Islamic law, customary law and state-centric state administration compatible.

Keywords: Legal geography, Indonesia, marriage, religious leaders, Islamic law 


\section{Introduction}

"A marriage is sweet, but if it is not registered, it becomes bitter."1

This statement by a legal expert and civil rights activist in an expert hearing on a new Bill touching family law (on 1 April, 2008) attests to the importance of marriage registration in Aceh, Indonesia. A marriage that has not been registered with the state administration leaves the individual rights and responsibilities of women, such as inheritance and child custody, in an administrative limbo. The bitterness the legal expert spoke of was widely felt, mostly by those women and their children, who had been affected by civil war (1976-2005) and the massive destructions caused by the 2004 Indian Ocean tsunami. This disaster not only ended the lives of many civil servants and destroyed much of the infrastructure of state administration but also washed away many documents. But although the importance of marriage registration seemed to be so clear to this activist, many Islamic leaders opposed the proposed new Bill, because neither Islamic law nor customary law explicitly prescribe marriage registration. Because Islamic leaders assume important roles in rural communities and are integrated into the provincial governmental administration, their voices had a strong impact on the political discussion in Aceh.

The key objective of this article is to analyse how Islamic leaders influenced administrative reforms that promoted the legal framework of marriage registration in Aceh, a province of Indonesia. Indonesia has a secular constitution, although it

\footnotetext{
1 Expert hearing on 1 April 2008, Drs. Rosmawardahni, member of the Expert Group - Tenaga Ahli Pansus, in view of the Parliamentary debate on population administration resulting in By-Law No. $6 / 2008$
} 
acknowledges the role of Islam. ${ }^{2}$ The role of Islam within statecraft is particularly pronounced in Aceh, because provincial religious authorities have special powers in law-making through Islamic law. In the nearly 30 years of conflict between the secessionist Free Aceh Movement (Gerakan Aceh Merdeka, GAM) and the central government of Indonesia, Islamic leaders maintained a decisive role in community management. During this time, the responsible offices for marriage registration in Aceh were largely dysfunctional, and Islamic leaders carried out wedding ceremonies, which brought legal validity to the relationship along religious and customary law, but did not make it legitimate in the eyes of the state administration. Islamic leaders were reluctant to submit their community social responsibilities to the administration of the state, because marriage registration, as governmental regulation, is an expression of the state's claim to an "epistemic sovereignty". Hannah $(2010,111)$ defines this form of sovereignty "as the (usually implicit) claim by states to a right to know what goes on in the territories they govern". Such claims follow the rationale of "territoriality-as-spatialstrategy" (Sack 1986; Murphy 2012, 159), i.e. the emergence of spatial arrangements by the centralised state to govern the populations within its national territorial boundaries.

I argue that while Islamic leaders are important stakeholders in law-making in Aceh, they are not a unified collective, but instead, mobilise a variety of different practices of legal reasoning to bring legal constructions into agreement. In Aceh, Islamic leaders include a variety of predominantly male Islamic authorities, such as government officials in the Consultative Council of Religious Scholars (Majelis Permusyawaratan Ulama Aceh, MPU), religious scholars in higher education, and Islamic leaders in

\footnotetext{
2 Belief in the one and only God (Ketuhanan Yang Maha Esa); the first principle of five in the Constitution.
} 
Islamic boarding schools (all called ulama), as well as Islamic leaders conducting Friday prayers (imam). I will show how Islamic leaders deliberate about contemporary social problems across their various different factions, using Islamic texts as the source of meaningful guidance for law-making. The Islamic texts mainly comprise the Qur'an (God's words), sunnah (the sayings of the prophet Mohammed) related to hadith (the traditions of the Prophet Mohammed), fiqh (Islamic jurisprudence) studied through the Yellow Books (kitab kuning ${ }^{3}$ ), literature of traditionalist Islamic education.

I trace the politics of Islamic leaders in the formation of family law in Aceh with a particular interest in the controversial issue of marriage registration. In order to understand the situated practices of legal reasoning in contemporary Aceh, I draw on a particular process of legal reasoning that took place in a multi-stakeholder forum involving Islamic leaders, civil servants and civil rights activists. This forum was designed to formulate legislation to reform registration of key life events (such as births, deaths, and marriages). During this process, the multiple legal constructions underpinned by Islam, as well as customary rights and state law, were made visible. This multi-stakeholder forum functioned between 2006 and 2008 as part of a larger reconstruction effort following the 2004 tsunami, which aimed to rebuild the state administration in the province of Aceh. The multi-stakeholder forum was facilitated by the German aid agency Deutsche Gesellschaft für Technische Zusammenarbeit (GTZ) as part of bilateral German-Indonesian development cooperation (for a more detailed discussion in general on tsunami aid in Aceh see e.g. Billon et al. 2007;

\footnotetext{
3 The Yellow Books are "Arab language works from Muslim writers of the middle period, which are studied in the Islamic boarding schools and together set the standards and paradigms for the graduates of those schools." (Federspiel 1995, 133)
} 
Hyndman 2009; Waizenegger et al. 2010; Hyndman 2011; Zeccola 2011; Daly et al. 2012). ${ }^{4}$

My main data corpus draws on interviews with civil servants working in the provincial government, Muslim actors, civil rights activists, national experts, international experts, politicians, and diplomats, with a total of 52 interviews mainly in Indonesian, English and German; and also analysis of background reports and legislative documents. I conducted these interviews when international aid programmes in Aceh were being phased out between 2009 and 2010. In addition, I used my observations in a professional assignment (2006) for the aid project "Supporting Population Administration in Aceh", which was implemented by GTZ, where I provided advice on organisational reform in the Acehnese provincial administration. However, I was not directly involved in the facilitation of the multi-stakeholder forum, which provides the site for my ethnographic analysis.

My analysis in this paper responds to three key concerns in legal geography. Firstly, I show that space and law are mutually constitutive in a context "out of the usual ambit of the largely urban, Global Northwest" (Kedar 2014, 95). In line with Delaney's (2016, 1) most recent request to analyse "the world of other places beyond Western common law", I look at the legal geography of a post-colonial Muslim context where Islamic, customary and state law are coexistent or interact. Secondly, I illustrate how those different types of law and "legal constructions" (Benda-Beckmann et al. 2014, 30) lead to arenas of power and subsequently a process of negotiation during law-making on marriage registration that is, at present, a legal practice mainly in urban areas. Thirdly,

\footnotetext{
${ }^{4}$ In this article, I do not specifically discuss the institutional setting of this "multi-stakeholder forum", as I am interested in the dynamics and practices of legal reasoning as such.
} 
multiple legal constructions provide different actors with different roles and options for mobilising power that is not only grounded in laws, but also creates "nomospheric technicians" (Delaney 2010, 71), "who seek to assert control and dictate outcomes within judicial settings as a means of advancing and consolidating their various agendas" (Benson 2014, 229). Studying the practices of legal reasoning by Islamic leaders and the powers located within such reform itself further resonates with recent calls among political geographers for a better understanding of religious leaders, their agendas and politics (Dittmer 2007; Sturm 2013; Tse 2013), as well as their hybrid position as non-state and state actors (McConnell et al. 2012, 812; McConnell 2013).

\section{Legal geography in post-colonial Muslim contexts}

Any legal reform of family law in Indonesia is squeezed between different legal constructions and their interpretive practices across state law, Islamic law (Sharia) and customary law. Generally speaking, customary law often corresponds with agreed rules and practices in a community, while Islamic law often regulates conduct and asserts universalist claims across scales (community, provincial, national, global) and is (re)interpreted by Islamic leaders. These different laws constitute, in Delaney's $(2010,25)$ understanding, a nomosphere that refers to "the cultural-material environs that are constituted by the reciprocal materialization of 'the legal' and the legal signification of the 'socio-spatial,' and the practical, performative engagements through which such constitutive moments happen and unfold". Delaney focuses not only on the spatial aspects of the legal, but also on the temporalities and forms of engagement. In the following I explain the spatial aspects of marriage registration as a governmental technique that aims to support and enable governing through state power vis-à-vis the legal aspects of Islamic law and customary law and their historical 
background. The mobilisation of these laws relates to 'geographies of nomospheres', i.e. differences in local, regional and national laws, practices and taken-for-granted assumptions. I show that legal reasoning and its rules of engagement go beyond the judicial review common in Western legal systems (Benson 2014), since different interpretations of Islamic law inform the 'practical, performative engagements' in lawmaking across customary, religious and state law.

In Indonesia, as in many postcolonial Muslim societies, Islamic law and customary law (adat) as forms of traditional law are merged with state law, but at times can be mobilised legally and politically against the realm of state law. "Sharia, in general, was not the product of Islamic government (unlike modern law, which is significantly the product of the state),"but a result of local communities providing their own legal experts in Islamic law" (Hallaq 2009, 8). Muslim communities were largely autarkic in their management and application of customary law, because the modern nation-state had not yet reached out to these mostly rural communities. As a result, "elaborate forms of local consensus making" (Geertz 1983, 211) resulted in local forms of customary law, for example for regulating the ceremonies of marriages. In this local self-regulation, the boundaries between customary law and Islamic laws became increasingly blurred: "Customary law was an obvious source of self-regulation, but the Sharia was equally important" (Hallaq 2009, 8). In Aceh, for example, "adat and sharî'a are invoked as new sources of hope for order and justice"5 (Bowen 2003, 17).

In Aceh today, Islamic law and customary law are closely intertwined. When Indonesia became independent in 1945, Islamic law was not explicitly included in the

\footnotetext{
${ }^{5}$ I use the English spelling of all Islamic terms and their pluralisations. In direct citations, I follow the spelling used in the original.
} 
Constitution. Since then, the project to anchor Islamic law in state law and governance has inspired a number of Islamic leaders and politicians in Indonesia, and even more so in Aceh. As religious law, Islamic law stands for a number of rationales: it promotes universal Islamic values, but can also be understood as having a disciplining agenda, for example on clothing in everyday life. Previously it had been used to provide sources for resistance to a too uniform state law by following "adat as "not-the-state"'” (Bowen 2003, 59). Currently, customary law serves as host for values and norms that regulate and, at times, discipline community life (Feener 2013).

Inherent in Islamic law is a tension between moral dimensions regulating conduct that are taken-for-granted norms beyond debate; and ethical questions that stimulate debate about the purpose and scope of managing a population in general (e.g. Johansen 1999; Asad 2003; Ramadan 2009). A set of moral norms provides guidance for personal ethics in the sense of moral conduct; for example, it would regulate the relationship of a young couple in love but unmarried. Islamic law as "a system of ethical injunctions as much as 'law' in the modern sense" (Hefner 2011, 2) considers Islamic law not only as a body of principles for moral conduct, but also as stimulating a set of (ethical) questions. In the latter understanding, Islamic law could provide ethical values, which inform legislative reasoning, not only in Islamic law, but also in presumably secular state law.

Within legal reasoning such tensions can be balanced by the imagination of different traditions within Islamic thought (Zaman 2002). "An Islamic discursive tradition is simply a tradition of Muslim discourse that addresses itself to conceptions of the Islamic past and future, with reference to a particular Islamic practice in the present" (Asad 1986, 14). Islamic legal traditions can be quite flexible and responsive to current 
issues because it is possible to interpret them in different ways. Its temporality allows readings and interpretations of Islamic texts which take into account the political context when the text was actually written. Practices of legal reasoning, which consider the temporality and integrity of the sources consulted, have been essential to influencing Islamic leaders' acceptance of the idea of marriage registration as being compatible with Islamic law, customary and state law. Put differently, "approaching the family as the result of a contract among individuals rather than as a part of an ongoing relationship among social groups" (Bowen 2003, 19) can conflict with the legal constructions of Islamic leaders who consider the family as a community affair.

These practices of legal reasoning further resonate with suggestions by legal geographers to consider not only the different socialisations of law, but also the contextual knowledge required before abstract law is made. This would imply understanding of the social context and inherent social problems when consulting Islamic texts for legal advice. Strictly speaking, following the Shafi'i school, the Quran is the highest source for any legal consultation, but other Islamic texts, such as the sunnah and the hadith, could be consulted, too (Ramadan 2009). The different ways to read, interpret and implement Islamic law on the basis of Islamic texts, but also customary law significantly shape the geographies of nomospheres in Muslim contexts that can lead to contentious law-making on marriage registration. 


\section{Contentious law-making on marriage registration}

Because Islamic leaders claimed a political stake in regulating family life through Islamic law, ${ }^{6}$ family law has been a prime locus of contentions over law-making in Aceh and Indonesia more broadly. In the nomosphere of post-colonial Muslim contexts, a marriage is subject to different understandings of what turns the wedding ceremony into a legally binding act. Within the broader field of family law, the registration of a marriage is important, because although a wedding ceremony might be witnessed by the public, the registration is the decisive step to link the marriage to a legal contract with rights and responsibilities, registered within a state bureaucracy (Azra 2003). Registration provides entitlements to social benefits and for the purposes of inheritance (Azhary et al. 2007; Yanggo et al. 2007). In consequence, the lack of marriage registration has caused legal insecurities all over Indonesia, especially for women and their rights (Komnas Perempuan [National commission on violence against women] 2006). In Aceh, the situation has been aggravated by the effects of decades of violent conflict and of the 2004 Indian Ocean tsunami.

A first obstacle that complicates law-making in the field of family law in Indonesia is the co-existence of parallel institutional responsibilities of state and Islamic administrations: two Ministries, differentiated by Muslim and Non-Muslim affiliations, deal with family affairs (marriage, divorce, and inheritance). During Indonesia's struggle for independence, different political groups fought over the role of Islam in the Constitution. While nationalist-minded groups argued for a largely secular

\footnotetext{
${ }^{6}$ A number of scholars have written on this topic, in particular analysing the entanglements of multiple legal constructions and their different meanings in Indonesia, among them scholars working on the intersection of legal studies (Katz et al. 1975; Cammack 1999; Hanstein 2002; Mulia et al. 2007; Cammack et al. 2015) and area studies (Azra 2003; Salim et al. 2003a; Salim et al. 2003b; Feener 2013).
} 
Constitution, Islamist voices aimed for Islamic law to be included in political rule and statecraft. The Ministry for Religion was created in 1946, entrusted with the supervision of the Islamic Courts and of the Office for Religious Affairs (Kantor Urusan Agama, KUA) to regulate all Muslim affairs, including family matters and civil registration. The Ministry of Home Affairs and its subsidiaries were given the task of registering non-Muslims and managing their family matters.

Disputes about law-making for marriage registration have continued since Dutch colonial times. In 1973, a legal draft sparked high emotion because it addressed the regulation of polygamy, child marriage, and the regulation of property in cases of divorce. It proposed to delegate all issues related to marriage and divorce to the civil courts, but this provoked a protest from Muslim actors who wanted to keep a dual administration (Muslim and non-Muslim) (Katz et al. 1975). As a result, the revised draft regulated polygamy, divorce, the control of population growth, and the formal establishment of legal rights for women (Azra 2003; Cammack 2007) and delegated all issues related to Muslim family affairs to the Islamic Courts, called Sharia Courts in Aceh. The subsequent National Marriage Act, Law No.1/1974 addressed a number of the original issues, but legal registration of marriage by the state was made optional.

Marriage registration remains in a legal limbo, despite law-making efforts since the fall of Indonesia's authoritarian former president Suharto and the period of democratisation (reformasi) that followed. Article Two of the National Marriage Act (Law No. 1/1974) comprises two subsections that are still valid. Subsection 1 states: "A marriage is legitimate if it has been performed according to the laws of the respective religion and beliefs of the parties concerned." Sub-section Two states: "Every marriage shall be registered according to the laws in force" (Hooker 2008, 15). 
The first subsection assigns the validity of a wedding ceremony to traditional law, while the second sub-section makes registration a mandatory state practice.

In 2004, the Ministry of Religion tasked Siti Mulia, a human rights activist and Islamic legal scholar, with developing the Counter Legal Draft (CLD) that advocated a range of measures promoting gender equality. Various societal groups, including moderate Islamic leaders, rejected the CLD. "The CLD did not fit in the tradition of Islamic law and the Islamic courts in Indonesia, as many Reformasi or Dutch civil law norms in the 1974 Marriage Act and the Compilation of Islamic Marriage are also in direct conflict with traditional fiqh" (Cammack et al. 2015, 22). Among the variety of Islamic texts, the fiqh texts are important forms of guidance, although they do not specify the administrative act of marriage registration. Hooker $(2008,1)$ considers these as "fundamental, but no longer primary on a day-to-day basis": Figh texts are consulted more and more selectively, leading to the varying nature of Islamic law.

The Compilation of Islamic Law (Kompilasi Hukum Islam, KHI), enacted in 1991 through Presidential Instruction No. 1, was a response aiming to unify and codify the variety of figh. Although the $\mathrm{KHI}$ is not legally binding, it intended to provide a pacifying response to text-focused interpretations of the variety of sources (Salim et al. 2003b). Moreover, the $\mathrm{KHI}$ aims to regulate all Muslim family affairs, but does not cover NonMuslim family affairs. In Aceh, the KHI serves as a guide in the state Sharia Courts (mainly handling divorces and inheritance disputes) alongside the Religious Judicature Act (1989), while references to figh are rather rare (Feener 2013, 169). The most recent reform of the $\mathrm{KHI}$ in 2010 addressed the registration of marriages (including involuntarily unregistered marriages, voluntarily informal polygamous marriages, and temporary marriages). Women's organisations opposed the reform Bill 
because it would have restricted the choice of sexual relationships (Cammack et al. 2015, 22).

These developments in the institutionalisation of Islamic legal reasoning need to be contextualised within the increasing political importance of Islamic law, which has prevailed in Aceh since the 1960s. Islamic law has been more and more institutionalised as part of regional regulations (Peraturan daerah-Perda Syariat), even during the times of the civil war between Indonesia's central government and Aceh's Independence Movement, GAM. The institutionalisation of Islamic law started with the passage of the Syiar in 1963, which stated that Muslim festivities and religious practices should be commonly observed. The state's Islamic agenda was not counteracted by the separatist agenda propagated by GAM.

In attempts to undermine support for GAM, the central government issued two laws strengthening the role of Islamic law in Aceh's provincial law-making: Law 44, enacted in 1999 and Law 18 in 2001, institutionalised Islamic law not only as the main source for law-making in the realm of religion, local customs and education, but also strengthened its implementation, including reinforcing Islamic law courts through the Perda Syariat (Salim 2009) and, in particular, strengthening the role of Islamic leaders (Aspinall 2009, 209; Miller 2009, 90f). In 2006, the Law of Government of Aceh (LoGA), following the peace truce (Helsinki Memorandum of Understanding, 2005) marked an end to the war between GAM and the central government of Indonesia, and paved the way for self-government in Aceh. The LoGA defined the role of Islamic law as covering belief, law and morality. Through the introduction of various legal regulations, Islamic law gained more leeway as a political instrument for informing statecraft, which led to different roles of Islamic leaders as nomospheric technicians. 


\section{Different roles of Islamic leaders in Aceh}

Islamic leaders are of particular importance in the implementation of the Perda Syariat, which allows interpreting Islamic law as set of moral principles and ethical values. Islamic leaders serve not only in governance, but also as active agents in political life and underlying rationales (Dittmer 2007, 737) and in law-making they are 'nomospheric technicians' because within law-making, Islamic leaders apply different interpretive practices related to their place of origin, educational background, and social function. An important characteristic is the often hybrid status of Islamic leaders' state and non-state affiliations. The state implementation of Islamic law has been an attempt to streamline and eventually to overcome such hybridity.

Area studies scholars working on Indonesia roughly assign Islamic leaders and different factions to two main religious schools: very generally speaking, one is propagated by intellectual, often modernist, educated urban state workers; and the other is called traditionalist and more common in rural areas (e.g. Hooker 2008; Feener 2013). They draw on different sources and interpretations of Islam in relation to the common good, and hence are relevant to marriage registration. Islamic legal texts in the "Yellow Books", which are used as authoritative guides, are often related to a "traditionalist" position. Broadly speaking, a "traditionalist" position is open to locally derived, culturally embedded religious practices, such as Sufism. A "modernist" perspective, however, emphasises human reason and may reject local practices, such

as Sufism. Van Bruinessen $(2013,29)$ remarks that this rigid categorisation into 'traditional' and 'modern' neglects the blurred nature of such boundaries in Indonesia due to the emergence of different Islamic networks that apply manifold theological narratives. In the interviews I conducted, those labels were also used, albeit in slightly 
different articulations: "modernist" leaders were often called "intellectual ulama", while "traditionalist" leaders were referred to as "dayah school".

Islamic leaders have taken on many formal and informal roles in community management as well as state administration. Islamic boarding schools have always been run by local Islamic leaders, whether state or non-state, and often follow the dayah school. The interview participants I spoke to stressed the strong influence of the local leaders who adhere to the dayah school, despite the 1975 broader pedagogic reform by the central government aimed at building a strong sense of shared national identity. Such a measure is in line with state Islamisation or the dawa paradigm that has "the explicit intention of using Islam both as a means of maintaining social and political order, and as an instrument to steer social change in directions that facilitate the goals of national economic development" (Feener 2013, 4). Especially in tertiary education institutions, dawa promotes an official version of a state-propagated Islam. However, state Islamisation has not affected certain roles of non-state Islamic leaders in rural communities, as the widespread presence of unregistered marriages shows.

The dawa paradigm of state Islamisation aimed to clarify the various roles of Islamic leaders within the state administration of Indonesia. In 1965, Acehnese Islamic leaders were granted status as senior officials within the Consultative Council of Religious Scholars, the MPU. This affiliation was just the starting point for anchoring new political functions in the Acehnese government (Feener 2013, 93-128). Two points are decisive for debating law-making in this context: first, in Regional Regulation No. 3, of 2000, the MPU was tasked with "working parallel to and in equal partnership with the provincial government and the legislative assembly" (Feener 2013, 105). Secondly, Regional Regulation No. 9/2003 gave the MPU the right to provide legal advice 
(fatwa), with or without a formal request from the government. A fatwa by the MPU is important since it reflects a religiously-inspired opinion produced by governmental actors. However, in the following analysis of a process of reasoning, we will see that deliberations can emerge beyond the state /non-state divide as well as beyond positions of religious schools (traditionalist / modernist).

\section{Reform from inside: Combining source and meaning towards an ethical dimension}

In this section, I illustrate the role of Islamic leaders as nomospheric technicians in the development of legislation for the registration of marriages in Aceh in a particular lawmaking process that took shape in the post-tsunami reconstruction process. In particular, I analyse the legal reasoning process in the multi-stakeholder forum that was designed to support the integration of Islamic leaders into the legislative process of establishing marriage registration in the civil administration of Aceh. This multistakeholder forum involved Islamic leaders, civil servants, women activists and local and international experts who discussed the registration of vital life events, including marriage registration. Understanding and including the broad variety of Islamic leaders and their respective positions in the process of dialogue was a challenging aspect of forging common understanding and ultimately increasing participation in law-making (Cornwall et al. 2007). I explore how specific Islamic legal traditions have been used to help resolve the apparent deadlock between the different legal constructions and the variety of legal traditions and their interpretive practices.

This multi-stakeholder forum was deemed necessary because marriage registration was highly controversial among Islamic leaders in Aceh. For some, marriage 
registration was perceived as a mechanism of state management in which customary law was being replaced by an individualising law in line with the administrative apparatus of a modern nation-state. Resistance to this mechanism came largely from Islamic leaders of the dayah school, who often work in Islamic boarding schools and enjoy high public recognition. These Islamic leaders feared that the registration of marriages would symbolically and practically reduce their influence in local communities and givee broader powers to the state.

Through marriage registration, spouses gain individual rights, and the recognition of family relationships is detached from the locus of the wedding ceremony: this has the effect of increasing the legal grounds for women to participate in social life. In turn, however, the increased physical and social mobility of women specifically poses various challenges to community life and prevailing customary law. In an interview (6 November 2010), a high-ranking government official working on customary law in Aceh pointed out that access to new means of communication and transport have increased the mobility of women. This research participant explained that adultery and even polygamy, are more likely to occur further away from home. The implication is that Islamic and customary law regulate life within an assumed settled community and that their reach does not extend to people who travel to other places. Another challenge, rather opaquely voiced in interviews with government officials but openly addressed by women activists, is the existence of purposefully unregistered marriages, some of which are polygamous. The $\mathrm{KHI}$ allows men to marry up to four 
women, subject to economic viability. ${ }^{7}$ In most cases, these polygamous marriages take place discreetly, and are often not officially registered (Van Huis et al. 2012).

The importance of including Islamic leaders in legal reasoning about family law was made clear to me by a civil servant, who emphasised the leaders' high social standing in rural communities. This research participant considered marriage registration as a 'Western' concept, which could not simply be implemented without consulting Islamic leaders:

"Here the culture is very close to the Sharia, $100 \%$ religion, Islam. So if we convey something new, with a new perspective, something with a good intention, then it's good if it is in line with Islam [...] because they reject ideas that seem to be Western in origin. [...] If something new is conveyed to people who are not familiar with a Western perspective then people will doubt it. If something new was conveyed before in an inappropriate way, then the approach needs to relate to public actors, religious leaders, because the people here relate it to Islam." (Interview 10 November 2010)

The proponents of the dayah school are important interlocutors within law-making because their physical presence in rural areas and related quotidian practices provide them with local legitimacy. Two leading proponents of the dayah school reiterated the leverage local leaders had in any decision-making process made by the provincial state government (Interviews, 5 November 2010; 9 November 2010). One of these two research participants, a member of the MPU, emphasised the leverage of power through a strong physical presence and explained how crucial it was to work with the

\footnotetext{
7 KHI, Art. 55
} 
representative of the dayah school in the area. Backing up decisions on worldly matters by referring to beliefs spelled out in Islamic written sources was a deciding factor in having reforms and changes, emphasised by one civil rights activists:

"The shortcoming of our Islamic leaders in Aceh is that the ulama dayah still read the old Yellow Books, not the modern ones. Thus they do not understand how to develop a contemporary Muslim population. So they might rely on former interpretations of the Islamic textual sources, [and] in consequence they just see that something is illegitimate [haram] and they do not know how to find a solution because they do not know about the contemporary Yellow Books." (Interview 5 November 2010)

This activist saw the role of Islamic leaders as crucial in an administrative process such as marriage registration: and she further noted that:

"The ulama dayah are also decisive in handling unregistered marriages. In the rural areas, there are unregistered marriages because local leaders such as the imam or the head of the village think that the marriage certificate is not necessary. The problem is rather located in the towns, where there is mobility and people move. So in town things are getting tricky. For example, there are already disputes about property. And sometimes there is someone who marries again, without the consent of the first wife. And for sure the first wife is getting angry with the second wife, because the second wife might ask for a certificate. This would not be possible in the rural contexts." (Interview 5 November 2010) 
This quote not only explains the problems caused by unregistered marriages, it also highlights the different nomospheres: seemingly people accept unregistered marriages and their lives are not affected because they continue in these traditions, while Islamic leaders assume a kind of administrative function as well as social control. While customary law is or was essential to the organisation of community life, it becomes more and more apparent that state management, exemplified here by marriage registration, is confined to the "urban" registration office. In consequence, the "state" becomes a purely urban phenomenon, while local leaders in rural Aceh govern along different, community-based lines.

The process of legal reasoning (ijtihad) has a long tradition in Sunni Islam. It follows different judicial approaches within different legal schools. The Shafi school follows a deductive pattern of legal reasoning, requiring normative markers before coming up with tailor-made answers for contemporary problems (Ramadan 2009). The example presented here draws on similar processes. In this case, Islamic texts were specifically consulted and discussed in order to justify a legal regulation brought forward by a state legislative process. In a study of Indonesia, Rifyal Ka'bah (2007) discusses examples of ways in which non-legislative processes of developing Islamic law took place in selected non-state Islamic institutions. He shows that legal reasoning can be an established element within non-legislative processes and, also, that there is considerable variation in the sources consulted. Such legal reasoning might not be accepted in certain Islamic organisations or schools of thought. However, in Aceh, legal reasoning became more inclusive: a fatwa issued in 2008 by the MPU explicitly permitted legal debate between Islamic leaders recognised by the provincial state of Aceh, including those from different factions, such as the dayah school. The MPU 
aimed specifically to encourage exchanges of different perspectives between different factions of Islamic leaders (Feener 2013, 115-16).

These different legal perspectives within Islamic law also played out in the legislative process on marriage registration in Aceh. A high-ranking official in the Sharia State Agency emphasised the importance of winning over proponents of the dayah school initially opposed to registration:

"The Islamic leaders adhering to the dayah school had also been invited. Most of them have understood the difficulties emerging from unregistered marriages. This was progress, compared with previous times where they were solely concerned with the figh. But [nevertheless] a good deal of the dayah school belonged to the conservative [traditionalist] camp [and still] insisted on their position." (Interview 4 November 2010)

Many research participants lamented the divide between the different factions of Islamic leaders and considered the discussions in the multi-stakeholder forum as vital to bridge the different factions. More explicitly, one participant pointed out the need to come to an understanding of marriage registration to clarify the Islamic leaders' role, since the Islamic texts did not cover it. This resonates with Hooker's $(2008,1)$ analysis of Indonesia that "even the contemporary calls for an 'Islamic state' [...] do admit the necessity for a modern bureaucratic structure and some degree of legal borrowing from outside the syariah [Sharia]". It was important for all those involved in the process to consult Islamic texts relevant to marriage registration. A high-ranking official in the MPU pointed to both the importance of the exchange of opinions on registration and 
the importance of justifying marriage registration through a reference to the hadith (Interview 10 November 2010).

The "ethical injunctions" (Hefner 2011, 2) of Islamic law and expectations for the future were important references in the discussion in the multi-stakeholder forum. Firstly, the nature of figh (to bring advantage to, and avoid danger for, the society) was crucial in proving the integrity of Islamic texts to the satisfaction of the dayah school. A slightly stronger reference in relation to marriage registration is included in the hadith, as the member of the MPU emphasised (Interview 10 November 2010). The hadith highlights the well-being of siblings (Yanggo et al. 2007, 16-7) which the Qur'an also refers to. ${ }^{8}$ This research participant, like others, stressed that figh was an essential Islamic source for Islamic leaders of the dayah school, necessary to the law-making process.

In this section, I have shown the interplay of different legal traditions within Islamic law and different practices of legal reasoning drawn on to address controversies around law-making in family law, in this case, marriage registration in Aceh. Consulting written Islamic texts was an important step in acknowledging the integrity of Islamic traditions, while considering the experience and expectations of political challenges. These approaches are grounded in legal tradition in Sunni Islam and aim to resolve divergent opinions among Islamic leaders. In Islamic reasoning this might necessitate increasing the range of texts that are accepted as valid references in the discussions. In the case studied here, it was the reference to the hadith that reconciled different nomospheres, where a wedding ceremony turns not only into a legal act by being witnessed, but is

\footnotetext{
${ }^{8}$ E. g. al-Baihaqy: "The rights of a child from their parents are [that] the parents should teach the child to write, swim, shoot, and not to provide a livelihood except that which is good."

Al-Nahl: 72: "And Allah hath given you wives of your own kind, and hath given you, from your wives sons and grandsons, and hath made provisions of good things for you."
} 
also linked to the administration of the state through its registration. Islamic leaders came to accept civil registration as being in the interests of the well-being of the community, although it is not compulsory by law.

\section{Conclusion}

This article has analysed how Islamic leaders influenced administrative reforms that led to the establishment of a new legal framework that addresses the registration of marriages in Aceh, Indonesia. Thereby I have responded to Kedar's $(2014,95)$ and Delaney's $(2016,1)$ call to analyse research sites that are not only beyond the Global Northwest, but also beyond those constituted by Western common law. Hence, in my argument I have disentangled the perception that Islamic leaders are a cohesive, unified collective, and shown that they mobilise different practices of legal reasoning, based on different legal constructions within Islamic law. Within the context of these reforms, Islamic leaders have debated issues concerning social problems across their different factions with the aim of addressing contemporary social problems. During these debates they have referred to advice embedded in written Islamic texts as meaningful sources for law-making.

A second contribution of this article has been to illustrate the coexistence and interaction of plural laws which prevail on different legal scales. While various reform processes have tackled marriage registration on the national level, legislation on marriage registration at the provincial level has remained deadlocked. Such deadlock results from the coexistence of customary and Islamic law that do not prescribe marriage registration for the predominantly Muslim citizens in Aceh. As long as traditional wedding ceremonies continue to be accepted social practice that also 
legally validates a marriage, social problems due to marriages being unregistered with the state remain unresolved. For example, domestic violence or lack of access to property cannot be addressed through recourse to law. The lack of state registration of marriages perpetuates the risks and sufferings of families who are denied recourse to legal redress for violence or lack of property rights. They are left to the mercy of community traditions and customary law, and are reliant on the moral courage of those in the community who speak out.

The third contribution of the article has addressed the role of Islamic leaders, in particular those adhering to the dayah school. They have been decisive for community management in rural areas, while other factions of Islamic leaders are part in the practice of government (for example, senior officials of the MPU). It was crucial to include those leaders in law-making processes aiming to harmonise national state law vis-a-vis local community management to promote state administration also in rural areas. It was especially the more traditionalist segment of the Islamic leadership who were reluctant to concede their central role in wedding ceremonies to the legal regulations of the state. Processes inherent to traditions in Sunni Islam and the ethical injunctions of figh and hadith promoted an understanding of the necessity for a "legal borrowing outside the Sharia" (Hooker 2008, 1). The figh provided normative advice on the well-being of the community, while certain hadith pointed out the importance of the well-being of siblings, relating to expectations in the future. The reference to Islamic texts was also crucial to the co-operation of the Islamic leaders of the powerful dayah school in the negotiation of changing positions within the post-colonial Muslim society of Aceh. The nomospheres of law-making shifted from the state and the region to place-based customary and Islamic traditions. 
In considering these intricate entanglements, (legal) geographers need to acknowledge more fully the different dynamics of law-making and nomospheric practices in legal settings outside of Western democracies in order to gain a more complex understanding of the varieties of legal geographies across the globe. It remains unknown, not only in Aceh, but beyond, how religious leaders exercise power and shape governing. When examining particular Islamic traditions or geopolitical narratives, future research agendas might ask what are the specific types of legal performance, whom do they address, and what kind of spaces are involved or even constituted. 


\section{References}

Asad T 1986 The idea of an anthropology of Islam Occasional Paper Series Center for Contemporary Arab Studies, Georgetown University/Washington D.C.

Asad T 2003 Formations of the secular: Christianity, Islam, modernity Stanford University Press, Stanford

Aspinall E 2009 Islam and nation National University of Singapore Press, Singapore

Azhary $\mathbf{T}$, Hasanuddin and Yanggo $\mathbf{H ~} \mathbf{J}$ Civil registration in the perspective of Islamic law. Experts in secular law, Islamic law and adat law 2007 Jakarta Deutsche Gesellschaft für Technische Zusammenarbeit-GTZ,

Azra A 2003 The Indonesian marriage law of 1974: An institutionalisation of the Shari'a for social changes in Salim A and Azra A eds Shari'a and politics in modern Indonesia Institute of Southeast Asian Studies, Singapore 76-95

Benda-Beckmann F v and Benda-Beckmann K v 2014 Places that come and go: A legal anthropological perspective on the temporalities of space in plural legal orders in Braverman I, Blomley N, Delaney D and Kedar A eds The expanding spaces of law: a timely legal geography Stanford University Press, Stanford 30-52

Benson M 2014 Rules of engagement: The spatiality of judicial review in Braverman I, Blomley N, Delaney D and Kedar A eds The expanding spaces of law: a timely legal geography Stanford University Press, Stanford 215-238

Billon P L and Waizenegger A 2007 Peace in the wake of disaster? Secessionist conflicts and the 2004 Indian Ocean tsunami Transactions of the Institute of British Geographers 32 411-427

Bowen J R 2003 Islam, law, and equality in Indonesia: An anthropology of public reasoning Cambridge University Press, Cambridge

Cammack M 1999 Islam, nationalism, and the state in Suharto's Indonesia Wisconsin International Law Journal 17 1-42

Cammack M, Bedner A and Van Huis S 2015 Democracy, human rights, and Islamic family law in post-Soeharto Indonesia New Middle Eastern Studies 5 1-24

Cammack M E 2007 The Indonesian Islamic judiciary in Feener R M and Cammack M eds Islamic Law in contemporary Indonesia Harvard University Press, Cambridge/MA 146-69

Cornwall A and Coelho V S 2007 Spaces for change? The politics of citizen participation in new democratic arenas Zed Books, London, New York

Daly P, Feener M and Reid A eds 2012 From the ground up: Perspectives on post-tsunami and postconflict Aceh Institute of Southeast Asian Studies, Singapore

Delaney D 2010 The spatial, the legal and the pragmatics of world-making: nomospheric investigations Routledge, London 
Delaney D 2016 Legal geography III: New worlds, new convergences Progress in Human Geography in print

Dittmer J 2007 Intervention: Religious geopolitics Political Geography 26 737-739

Feener M 2013 Shari'a and social engineering. The implementation of Islamic Law in contemporary Aceh, Indonesia Oxford University Press, Oxford

Geertz C 1983 Local knowledge: Further essays in interpretive anthropology Basic Books, New York

Hallaq W B 2009 An introduction to Islamic law Cambridge University Press, Cambridge

Hanstein T 2002 Islamisches Recht und nationales Recht: eine Untersuchung zum Einfluß des islamischen Rechts auf die Entwicklung des modernen Familienrechts am Beispiel Indonesiens Peter Lang, Frankfurt a.M.

Hefner R W ed 2011 Shari'a politics Indiana University Press, Bloomington, Indianapolis

Hooker M B 2008 Indonesian Syariah. Defining a national school of Islamic Law Institute of Southeast Asian Studies, Singapore

Hyndman J 2009 Siting conflict and peace in post-tsunami Sri Lanka and Aceh, Indonesia Norsk Geografisk Tidsskrift-Norwegian Journal of Geography 63 89-96

Hyndman J 2011 Dual disasters. Humanitarian aid after the 2004 tsunami Kumarian Press, Sterling

Johansen B 1999 Contingency in a sacred law Brill, Leiden, Boston, Köln

Ka'bah R 2007 Islamic law in court decisions and fatwa institutions in Indonesia in Feener R $\mathbf{M}$ and Cammack M E eds Islamic law in contemporary Indonesia. Ideas and Institutions Harvard University Press, Cambridge/MA 83-98

Katz J S and Katz R S 1975 The new Indonesian marriage law: A mirror of Indonesia's political, cultural, and legal systems The American Journal of Comparative Law 23 653-681

Kedar A 2014 Expanding legal geographies: a call for a critical comparative approach in Braverman I, Blomley N, Delaney D and Kedar A eds The expanding spaces of law: a timely legal geography Stanford University Press, Stanford 95-119

Komnas Perempuan [National commission on violence against women] 2006 Sebagai korban, juga survivor [As victims, also survivors. A report on documentation findings on the status of women IDPs' human rights in Aceh], Jakarta

McConnell F 2013 The geopolitics of Buddhist reincarnation: Contested futures of Tibetan leadership Area 45 162-169

McConnell F, Moreau T and Dittmer J 2012 Mimicking state diplomacy: The legitimizing strategies of unofficial diplomacies Geoforum 43 804-814

Miller M A 2009 Reform and rebellion in Indonesia Routledge, New York 
Mulia S M and Cammack M E 2007 Toward a just marriage law: Empowering Indonesian women through a Counter Legal Draft to the Indonesian Compilation of Islamic Law in Feener R M and Cammack M E eds Islamic law in contemporary Indonesia. Ideas and institutions Harvard University Press, Cambridge/MA 128-145

Murphy A B 2012 Entente territorial: Sack and Raffestin on territoriality Environment and Planning-Part D 30 159-172

Ramadan T 2009 Radical reform: Islamic ethics and liberation Oxford University Press, Oxford

Sack R D 1986 Human territoriality: Its theory and history Cambridge University Press, Cambridge

Salim A 2009 Dynamic legal pluralism in Indonesia: The shift in plural legal orders of contemporary Aceh Working Paper 110 Max-Planck-Institute of Social Anthropology, Halle/Saale

Salim A and Azra A eds 2003a Shari'a and politics in modern Indonesia Institute of Southeast Asian Studies, Singapore

Salim A and Azra A 2003b The state and the Shari'a in the perspective of Indonesian legal politics in Salim A and Azra A eds Shari'a and politics Institute of Southeast Asian Studies, Singapore $1-16$

Sturm T 2013 The future of religious geopolitics: Towards a research and theory agenda Area 45134 140

Tse J K H 2013 Grounded theologies: 'Religion' and the 'secular' in human geography Progress in Human Geography 38 201-220

Van Bruinessen M 2013 Overview of Muslim organizations, associations and movements in Indonesia in Van Bruinessen $\mathbf{M}$ ed Contemporary developments in Indonesian Islam: Explaining the "conservative turn" Institute of Southeast Asian Studies, Singapore

Van Huis S and Wirastri T D 2012 Muslim marriage registration in Indonesia: Revised marriage registration laws cannot overcome compliance flaws Australian Journal of Asian Law 13 1-17

Waizenegger A and Hyndman J 2010 Two solitudes: Post-tsunami and post-conflict Aceh Disasters 34 787-808

Yanggo H J, Alam S, Djamil F, Lewenton U and Lange M 2007 Marriages that are not registered by the government Experts in secular law, Islamic law and adat law 2 Deutsche Gesellschaft für Technische Zusammenarbeit-GTZ, Jakarta

Zaman M Q 2002 The 'ulama in contemporary Islam: custodians of change Princeton University Press, Princeton

Zeccola P 2011 Dividing disasters in Aceh, Indonesia: Separatist conflict and tsunami, human rights and humanitarianism Disasters 35 308-328 
